\begin{tabular}{|c|c|c|}
\hline 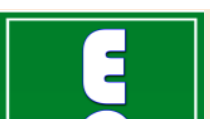 & $\begin{array}{l}\text { International Journal of Current Research in } \\
\text { Biosciences and Plant Biology }\end{array}$ & $=$ \\
\hline & Volume $7 \bullet$ Number 3 (March-2020) • ISSN: 2349-8080 (Online) & $\begin{array}{lll}\vdots & \\
\vdots \\
\vdots\end{array}$ \\
\hline $\begin{array}{l}\text { EXCELLENT } \\
\text { PUBLISHERS }\end{array}$ & Journal homepage: $\underline{w w w . i j c r b p . c o m}$ & \\
\hline
\end{tabular}

\title{
Performance of Saccharomyces carlsbergensis and Saccharomyces cerevisiae yeasts in the formulation of bioethanol from cashew apple residues
}

\author{
Gbohaïda Virginie ${ }^{*}$, Kouwanou Sagbo Cosme1, Bothon Fifa T. Diane ${ }^{2}$, \\ Olayé Théophile1, Agbangnan Dossa C. Pascal'1, Avlessi Félicien' \\ and Sohounhloué K. C. Dominique ${ }^{1}$
}

\begin{abstract}
${ }^{1}$ Laboratory of Study and Research in Applied Chemistry, Polytechnical School of Abomey-Calavi, University of Abomey-Calavi, Benin

2 Institut National supérieur de Technologie industrielle, Université Nationale des Sciences, Technologies Ingénierie et Mathématiques, Benin

*Corresponding author; e-mail: virginie.gbohaida4@gmail.com
\end{abstract}

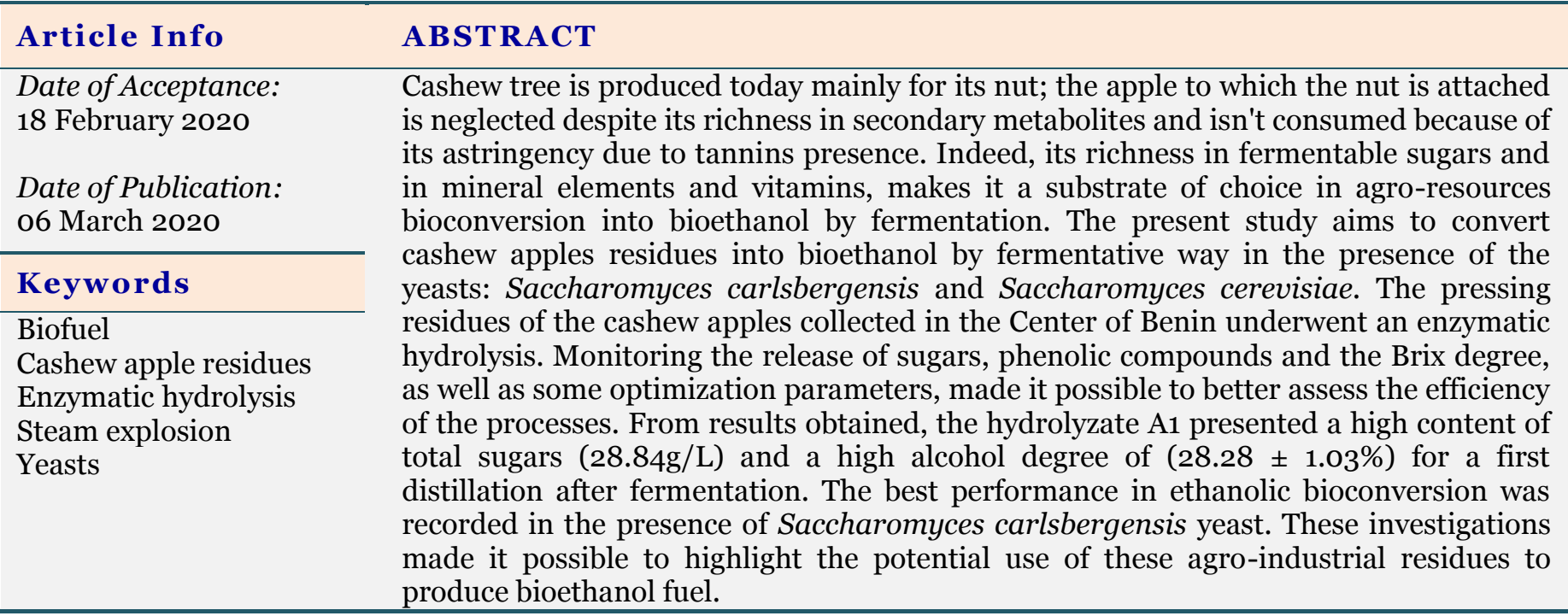

\section{Introduction}

In order to meet the growing global demand for automotive fuel and limit greenhouse gas emissions, the development of alternative fuels is becoming an important issue for research, both technologically and societally. One of the solutions being considered is the biochemical production of ethanol from neglected agro-resources (Adjou et al., 2017). Cashew apples (cashew tree's false fruit), raw materials are very available and have been few valued because of the cruel lack of fruit processing industries. They are often abandoned in garbage dumps located near the rare fruit 
processing units and in harvest fields (Gbohaïda et al., 2018a). The cashew apple, peduncle of the cashew tree fruit, is a by-product of the cashew nut which juice contains approximately $10 \%(\mathrm{~m} / \mathrm{v})$ of total sugars and the bagasse approximately $20 \%$ of cellulose (Prommajak et al., 2014). It's most often considered as a by-product of the cashew industry and remains very little valued despite its richness in secondary metabolites such as phenolic compounds, carotenoids, aromatic compounds (Soro, 2012, Venkatramana et al., 2018) and is not consumed because of its astringency due to the presence of tannins (Padonou et al., 2015). Indeed, besides the water content (86\%), the cashew apple has a high tannin content which limits its conservation for useful purposes. Nevertheless, in some countries it's processed into several products such as juice, jam, wine, vinegar and alcohol (Aboh et al., 2011).

According to Agbangnan et al. (2018a) the proximate composition of cashew apple was determined as: $12.32 \%$ of moisture, 6.45 to $12.5 \%$ of crude protein, 3.5 to $10.85 \%$ of total fiber, 30.6 to $54.7 \%$ total sugar (glucose), $30.8 \mathrm{mg} / 100 \mathrm{~g}$ of vitamin $\mathrm{C}$ and $12.48 \mathrm{MJ} / \mathrm{kg}$ of energy and minerals. After extracting the juice, the pressing residues can therefore be made available for the production of second generation bioethanol (Ware et al., 2019). The production of bioethanol by enzymatic biocatalysis of cashew apple residues is a study which consists of a bio-refinery of biomass to produce second generation bioethanol by various more suitable processes. Bioethanol comes from the fermentation of monosaccharides from the hydrolysis of cellulose and hemicelluloses, hydrolysis negatively affected by lignin impregnated on the cellulose-hemicellulose network. Lignin also has an inhibitory action on the microorganisms responsible for fermentation (Ghysel et al., 2010). The use of cellulose and hemicellulose for the production of bioethanol is hampered by the presence of lignin which is very difficult to degrade. The pretreatments make it possible to break the covalent bonds formed within the cellulose-hemicellulose-lignin complex, to degrade the hemicelluloses, to modify the properties of the cellulose and to redistribute the lignins (Chundawat et al., 2011). Bioethanol has many more advantages than conventional fuels because it comes from renewable sources (Ware et al., 2019). The present study proposes to evaluate the efficiency of yeasts on cashew apple's lignocellulosic residues for bioethanol fuel production.

\section{Materials and methods}

\section{Lignocellulosic substrate}

Cashew apples without distinction of varieties were collected by harvesting in fields of main cashew production areas ("Bantè", "Tchêti Doumè" and Savalou) of Bénin Center regions.

\section{Enzyme}

The enzyme used is Aspergillus niger cellulase with enzymatic activity of $1.14 \mathrm{U} / \mathrm{mg}$; from SigmaAldrich.

\section{Nutrient additive}

The nutrient additive used is Urea $\left[\mathrm{CO}\left(\mathrm{NH}_{2}\right)_{2}\right]$, from KEM LIGHT Laboratories PVT. LTD.

\section{Fermentation microorganisms}

Microbial strains used in this study are Saccharomyces carlsbergensis (So) and Angel brand Thermal-tolerant alcohol Dry yeast strain (S1), a variant of the species Saccharomyces cerevisiae from Chinese company «Ryan $\mathrm{Wu}$ /Angel Yeast Co., Ltd ».

\section{Musts preparation}

The cashew apples residues have undergone various successive operations (grinding pretreatment - enzymatic hydrolysis - sterilization) in order to obtain fermentation musts (Fig. 1). To facilitate the lignocellulose accessibility the pressing residues of cashew apples have been reduced into fine particles. The crushed were then pretreated by steam explosion in a thermometer Memmert oven for $20 \mathrm{~min}$ at $270{ }^{\circ} \mathrm{C}$. The enzymatic hydrolysis of pretreated cashew apples' pressing residues is launched by addition of Aspergilus niger cellulase at different concentrations (o; $0.5 ; 1$ and $1.5 \mathrm{~g}$ of enzyme per $\mathrm{kg}$ of substrate) at $\mathrm{pH}(4.5 \pm 0.2)$ and at $50{ }^{\circ} \mathrm{C}$ for 144h (Belmokhtar, 2012). The different samples were packed in plastic bags and incubated in an oven for entire hydrolysis' duration while 
maintaining the temperature at $50{ }^{\circ} \mathrm{C}$. In order to appreciate the effectiveness of the enzymatic hydrolysis process, the variation of total sugars' contents and of the phenolic compounds released were monitored using $1 \mathrm{~mL}$ of sample collected after 24, 48h, 72h, 96h and $144 \mathrm{~h}$ of hydrolysis. The enzymatic reaction was stopped by heating the sample in an autoclave $\left(120^{\circ} \mathrm{C}, 10 \mathrm{~min}\right)$. Urea was used as a nutrient at a concentration of $4 \mathrm{~g} / \mathrm{L}$ in order to favorably affect fermentation kinetics (Novidzro et al., 2013) Indeed, urea is a product which has a high content of nitrogen $(\% \mathrm{~N}=$ 46.67). The ethanolic fermentation was carried out on the filtered musts (A) and unfiltered musts (B) before fermentation of the different samples (Fig. 2).

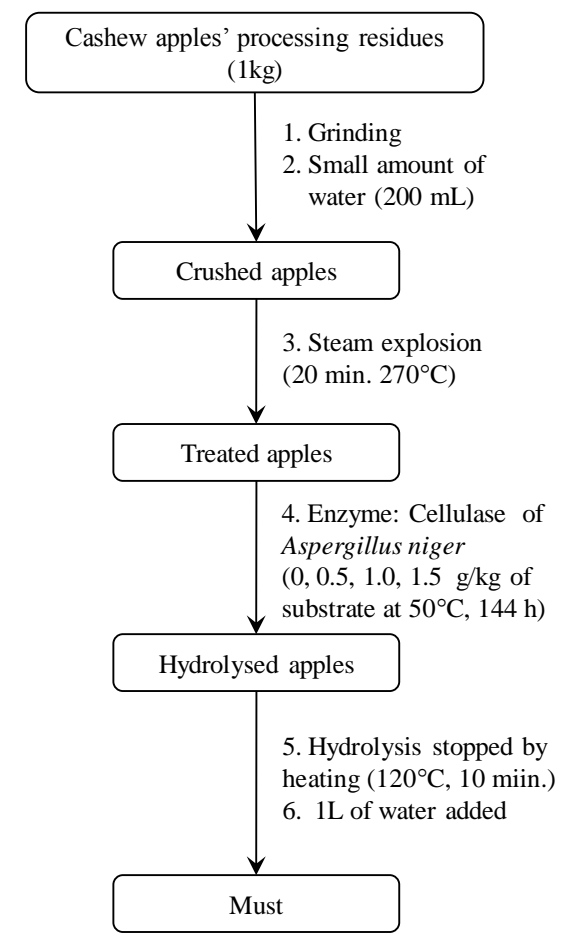

Fig. 1: Process for obtaining lignocellulosic biomass musts.

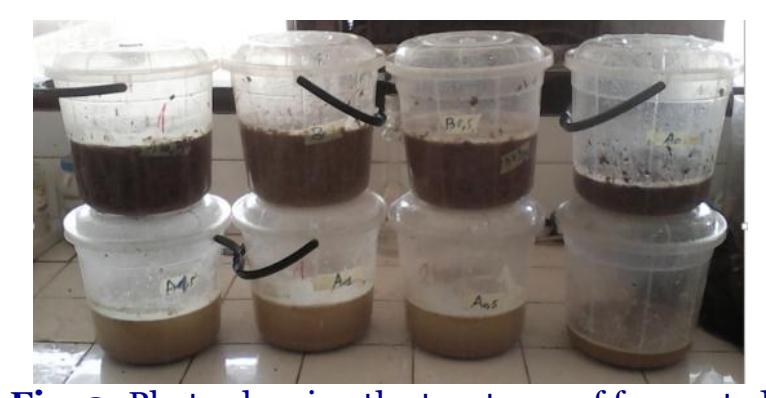

Fig. 2: Photo showing the two types of fermented hydrolysates.

\section{Inoculum preparation}

The yeasts Saccharomyces cerevisiae and Saccharomyces carlsbergensis were used as ferments. The inoculum was prepared by introducing $1.0 \mathrm{~g}$ of each dry yeast (lyophilized) strains into $9 \mathrm{~mL}$ of buffered peptone water (Gbohaïda et al., 2016).

\section{Fermentation process}

To acclimatize yeasts to the substrate, a prefermentation was carried out by incorporating the inoculum in $1 / 10$ of the total volume of sterile must to be fermented while leaving the mixture under stirring for $30 \mathrm{~min}$ in aerobic and an aseptic environment. Then the mixture was added to $9 / 10$ of the remaining sterile must volume. Thus urea, chosen as a growth factor, has been added to a concentration of $4 \mathrm{~g} / \mathrm{L}$ because of its usefulness for yeast growth, especially in the biosynthesis of amino acids, proteins, nucleic acids, vitamins, coenzymes and other functions like osmoregulation. The fermentation was carried out in batch mode. Each fermenter is kept tightly closed and musts' alcoholic fermentation took place for about seven (07) days.

\section{Alcoholic distillation}

At the fermentation's end, the ethanol contained in wines was extracted by fractional distillation at a temperature of $79{ }^{\circ} \mathrm{C}$ at column top.

\section{Analytic methods}

Total sugars: Total sugars content was evaluated according to colorimetric method with UV-Visible spectrophotometer using phenol-sulfuric acid (Dubois et al., 1956). Samples' total sugars content (ST) is determined from a calibration curve beforehand with D-glucose and expressed as gramm (g) equivalent of D-glucose per Liter (L) of juice.

Total polyphenols: Total polyphenols were assayed with Folin-Ciocalteu reagent (Agbangnan et al., 2018b). Folin reagent used consists of a mixture of phosphotungstic and phosphomolybdic acid which is reduced during the oxidation of the phenols into blue oxides' mixture of tungsten and molybdenum (Gbohaïda et al., 2015). Absorbance 
was measured on a spectrophotometer (JENWAY $5 \mathrm{O} / 60 \mathrm{~Hz}$ ) at $765 \mathrm{~nm}$. Gallic acid was used as a reference and juice's total polyphenol content was expressed as gram (g) equivalent of gallic acid per Liter (L) of juice.

Brix degree: Total soluble dry matter content (Brix degree) was determined during fermentation using a PAL 3-ATAGO portable digital refractometer. The alcoholic degree $(\% \mathrm{v} / \mathrm{v})$ of the various distillates was quantified according to pycnometric method recommended by AOAC (Sidney, 1984).

\section{Optimization parameters}

Fermentation optimization parameters determined are essentially fermentation duration $(\mathrm{t})$, limiting attenuation (AL), final ethanol content (Pexp), ethanol productivity $(\mathrm{Qp})$, Ethanol yield $\left(\mathrm{Y}_{\mathrm{p} / \mathrm{s}}\right)$ and production yield's efficiency (Ey). These parameters are determined according to the following formulas: $\mathrm{AL}=[($ Initial Brix - Final Brix $)$ $\mathrm{x}$ 100/Initial Brix] ; $\mathrm{Qp}=\mathrm{P}_{\exp }(\mathrm{g} / \mathrm{L}) /$ Duration (h) ; $\mathrm{Y}_{\mathrm{p} / \mathrm{s}}=$ Ethanol mass/Consumed sugar's mass et Ey $=\mathrm{Y}_{\mathrm{p} / \mathrm{s}} / \mathrm{o}, 54$ (Gbohaïda et al., 2018b).

\section{Results and discussion}

\section{Effect of pretreatment by steam explosion}

Steam explosion pretreatment is a very promising technique for lignocellulosic biomass before its bioconversion. It breaks hydrogen bonds that connect cellulose and hemicellulose molecules and allows efficient fractionation of constituent components (Jacquet et al., 2010), making them more available for enzymatic hydrolysis. The pretreatment was optimized at $270{ }^{\circ} \mathrm{C}$ for $20 \mathrm{~min}$. The results are shown in Fig. 3 and reveal the lignocellulosic material destructuration. These results concern phenolic compounds and total sugars contents on pretreated and untreated cashew apple residues. The pretreated sample had a phenolic acid content of $0.61 \mathrm{~g}$ gallic acid equivalent per Liter of juice and a total sugars content of $12.95 \mathrm{~g}$ D-glucose equivalent per Liter of juice, while the untreated residue was 1.5 times less rich in phenolic compounds $(0.42 \mathrm{~g} / \mathrm{L})$ and 2 times less rich in total sugars $(5.55 \mathrm{~g} / \mathrm{L})$. It appears that the steam explosion step has well initiated the fragmentation of chains of celluloses and hemicelluloses. The sugar release was noticed by the high total sugars content observed in the pretreated sample compared to the untreated sample. Pretreatment with steam therefore positively impacted the lignocellulosic substrate. This pretreatment was necessary to expose cellulose to enzyme attack (Eloutassi et al., 2014). In the literature, biomass pretreatment is absolutely essential for the biological stage because enzymes have very little activity on raw biomass (Boussarsar, 2008). In Benin, Kouwanou et al. (2018) worked on Eichhornia crassipes to produce second generation bioethanol and revealed the beneficial effect of steam explosion pretreatment in the cellulose's supply. After pretreatment, doing the hydrolysis and fermentation steps separately is better than when they are done simultaneously. The successive execution of the two processes makes it possible to appreciate optimum conditions, especially since enzymatic hydrolysis takes place between $40^{\circ} \mathrm{C}$ and $50^{\circ} \mathrm{C}$ and fermentation at about $30^{\circ} \mathrm{C}$ (Gbohaïda et al., 2018b).

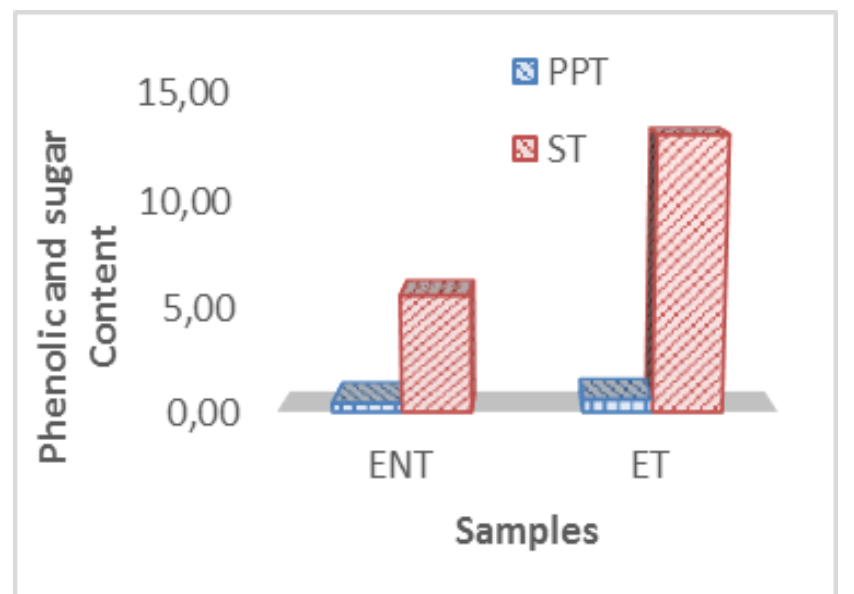

Fig. 3: Effect of pretreatment with steam explosion on cashew apple residues. ENT: untreated sample, ET: treated sample, ST: total sugars, PPT: total polyphenols.

\section{Enzymatic hydrolysis}

\section{Variation of fermentable sugars}

The relatively mild conditions under which the enzymatic hydrolysis is carried out make it possible to avoid denaturing the initial molecules and to reduce process cost (Eloutassi et al., 2014). Fig. 4 translating fermentable sugars release during enzymatic hydrolysis shows a progressive increase in the sugars content during the process. 


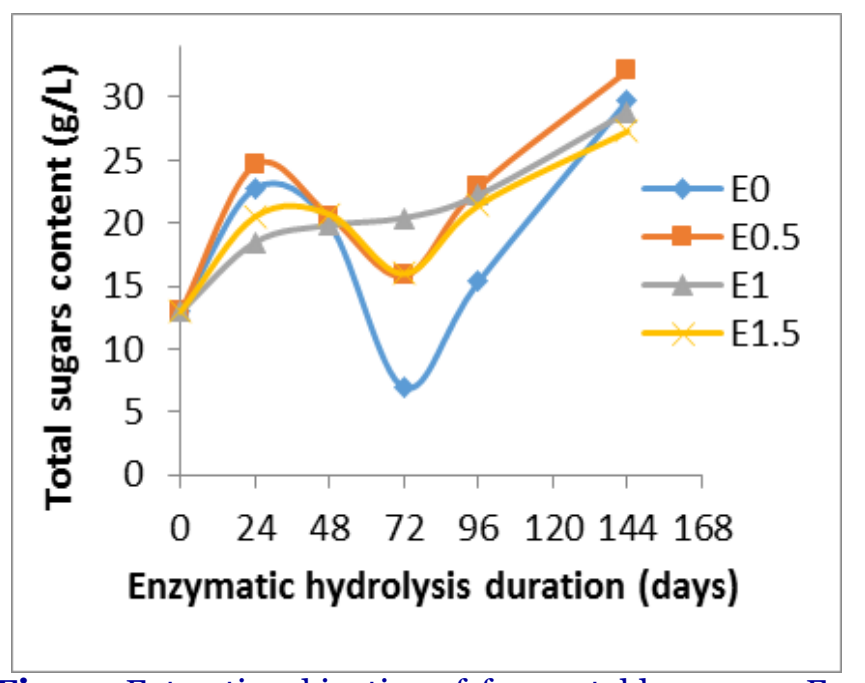

Fig. 4: Extraction kinetics of fermentable sugars. Eo, E0.5, E1 and E1.5: pretreated samples having respectively received the concentrations (0, 0.5, 1 and $1.5 \mathrm{~g} / \mathrm{kg}$ ) of Aspergillus niger's cellulase.

The results show a gradual release of sugars during the $144 \mathrm{~h}$ of hydrolysis, especially in the sample which received $1 \mathrm{~g}$ of enzyme for $1 \mathrm{~kg}$ of pretreated residue. The highest total sugars content of $\mathbf{2 8 . 8 4}$ $\mathrm{g} / \mathrm{L}$ was recorded in the hydrolyzate A1. This result is close to the value $22.5 \mathrm{~g} / \mathrm{L}$ obtained by Eloutassi et al. (2014) during the acid hydrolysis of residual biomass from the rosemary distillation industry in Morocco. The enzymatic hydrolysis with the Cellulast carried out at $45^{\circ} \mathrm{C} ; \mathrm{pH} 5.0$ during $72 \mathrm{~h}$ on cashew apple residues did by Rocha et al ., (2009); showed that pretreated with a sodium hydroxide solution had a glucose content $(466 \pm 81 \mathrm{mg} / \mathrm{g})$, ten times higher than that with dilute sulfuric acid $(47 \pm 5 \mathrm{mg} / \mathrm{g})$. It reveals the enzyme beneficial effect on glucose release. Kouwanou et al. (2018) obtained an increase in glucose content after enzymatic hydrolysis ranging from $4.32 \mathrm{mg} / \mathrm{mL}$ to $21.46 \mathrm{mg} / \mathrm{mL}$ in their investigations on Eichhornia crassipes. This confirms the release of sugars during the pretreatment process, favorite alcoholic fermentation stage.

\section{Phenolic compounds variation}

Enzymatic hydrolysis generates few phenolic compounds; effluents and doesn't cause corrosion problems (Didderen et al., 2010; Eloutassi et al., 2014). Within 48 hours, it is found that the maximum of the phenolic compounds has already been extracted. The highest content of phenolic compounds is around $8 \mathrm{~g} / \mathrm{L}$ (Fig. 5).

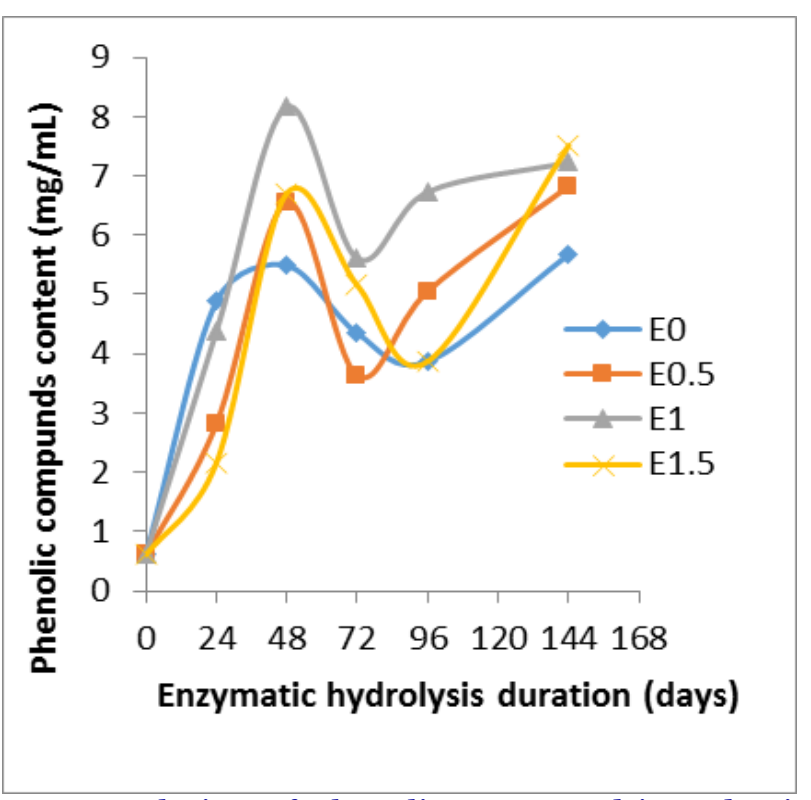

Fig. 5: Evolution of phenolic compounds' production during enzymatic hydrolysis.

\section{Variation of the Brix degree during the fermentation process}

Monitoring the Brix degree makes it possible to better control the evolution of the alcoholic fermentation process. The stabilization of Brix means the bioconversion process' end. Fig. 6 and Fig. 7 show the evolution of the Brix degree during hydrolysates fermentation in the presence of So and S1 strains respectively. The fermentation cessation was observed at different times in the process. A more rapid decrease in the Brix degree was revealed in the non-hydrolyzed sample. It confirms the low availability of fermentable sugars in this substrate not treated with the enzyme compared to hydrolysates. Also, it was noted that with So, the Brix degree did not change after $72 \mathrm{~h}$ of fermentation; while with $\mathrm{S} 1$, the Brix stop was observed after 96 hours of fermentation. It means that fermentation duration depends on strain type used.

\section{Alcoholic degree of distillates}

Results in Table 1 show a significant difference between alcoholic degrees obtained with So and S1. The lowest ethanol levels: $(1.07 \pm 0.02 \%)$ to $(2.77$ $\pm 0.10 \%)$ were obtained in the non-hydrolyzed samples. The samples hydrolyzed with cellulase, had a best alcohol contents $(12.64 \pm 1.00 \%)$ to $(28.28 \pm 1.03 \%)$. The high value of alcoholic degree 
$(28.28 \pm 1.03 \%)$ was obtained on A1 fermented with So. It was followed by A1.5 $(22.87 \pm 2.02 \%)$ and Bo.5 $(22.51 \pm 2.02 \%)$ in the presence of $\mathrm{S} 1$. Vaitheki and Deepa (2016) in India had worked on pineapple peelings' hydrolysates obtained by thermal pretreatment and obtained an alcohol content of $7.2 \%$ after $72 \mathrm{~h}$ of fermentation. Another work on the fermentation of residual flour after acid hydrolysis revealed pure ethanol content of 42\% (Ware et al., 2019).

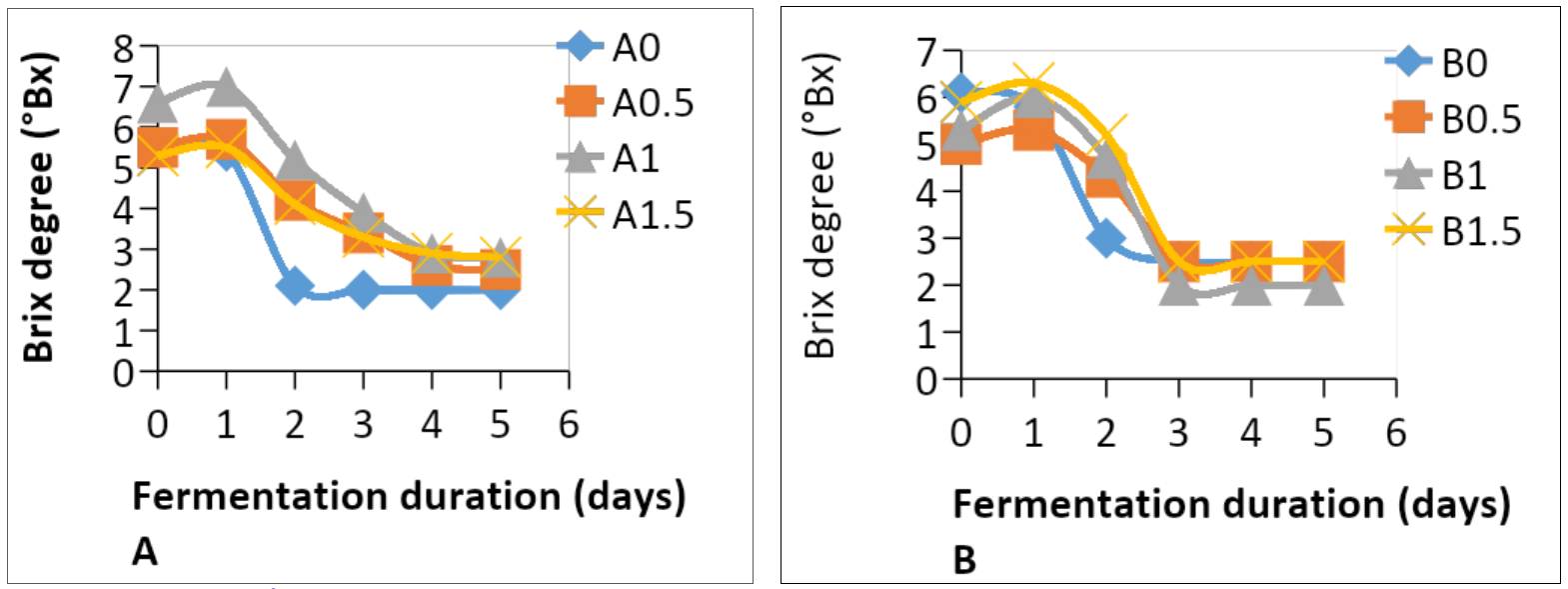

Fig. 6: Brix degree's evolution during fermentation with So (A and B).

A: filtered musts; B: unfiltered musts.
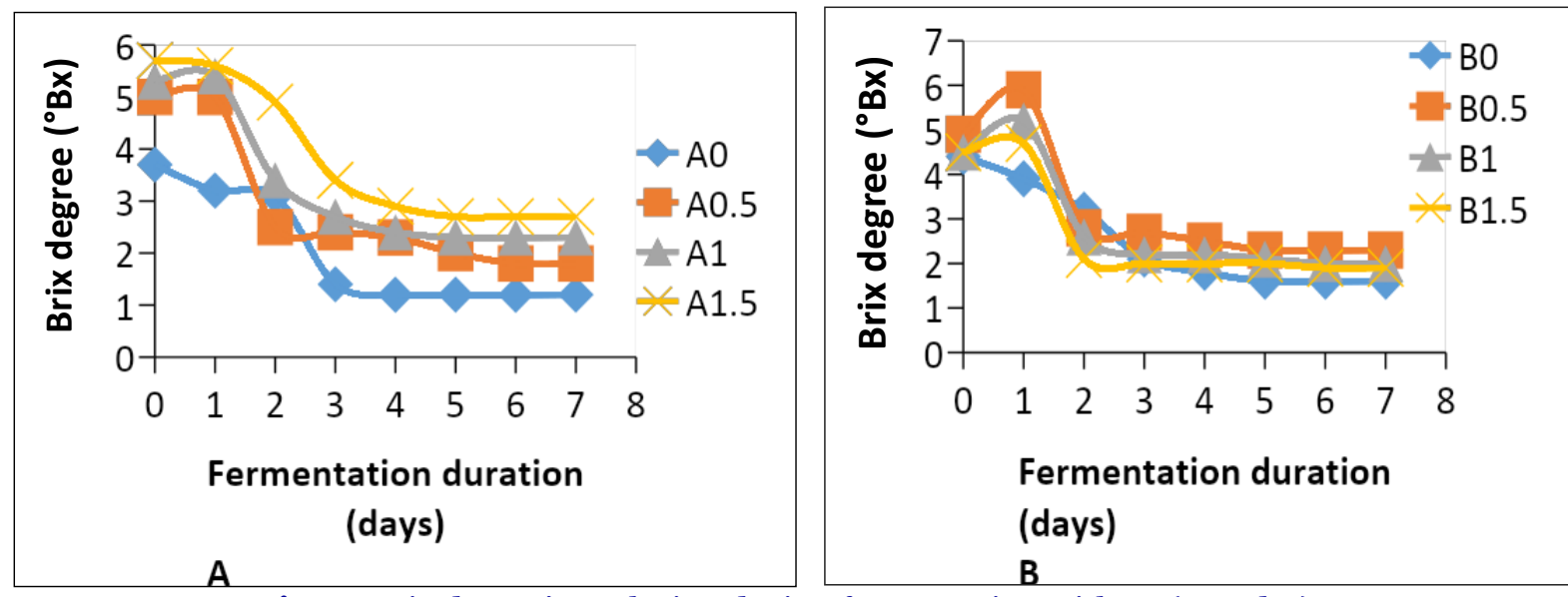

Fig. 7: Brix degree's evolution during fermentation with S1 (A and B).

Table 1. Alcoholic degree of distillates obtained from hydrolysates (\% v/v).

\begin{tabular}{|c|c|c|c|c|c|c|c|c|}
\hline & \multicolumn{4}{|c|}{ Filtered hydrolysates (A) } & \multicolumn{4}{|c|}{ Unfiltered hydrolysates (B) } \\
\hline So & $\begin{array}{l}2.77 \pm \\
0.10^{\mathrm{e}}\end{array}$ & $\begin{array}{l}19.83 \pm \\
1.02^{b}\end{array}$ & $\begin{array}{l}28.28 \pm \\
1.03^{\mathrm{a}}\end{array}$ & $\begin{array}{l}18.59 \pm \\
1.02^{\mathrm{b}, \mathrm{c}}\end{array}$ & $\begin{array}{l}2.73 \pm \\
0.10^{\mathrm{e}}\end{array}$ & $\begin{array}{l}17.20 \pm \\
1.02^{\mathrm{c}, \mathrm{d}}\end{array}$ & $\begin{array}{l}15.55 \pm \\
1.06^{d}\end{array}$ & $\begin{array}{l}17.84 \pm \\
1.08^{\mathrm{b}, \mathrm{c}, \mathrm{d}}\end{array}$ \\
\hline S1 & $\begin{array}{l}1.07 \pm \\
0.02^{\mathrm{d}}\end{array}$ & $\begin{array}{l}18.97 \pm \\
1.01^{\mathrm{b}}\end{array}$ & $\begin{array}{l}12.64 \pm \\
1.00^{c}\end{array}$ & $\begin{array}{l}22.87 \pm \\
2.02^{\mathrm{a}}\end{array}$ & $\begin{array}{l}1.88 \pm \\
0.21^{\mathrm{d}}\end{array}$ & $\begin{array}{l}22.51 \pm \\
2.02^{\mathrm{a}}\end{array}$ & $\begin{array}{l}17.29 \pm \\
1.02^{\mathrm{b}}\end{array}$ & $\begin{array}{l}16.45 \pm \\
1.07^{\mathrm{b}}\end{array}$ \\
\hline
\end{tabular}

In the same line, the values sharing no letters are significantly different $(\mathrm{P}<5 \%)$ according to ANOVA and Tukey's multiple comparison tests. 


\section{Hydrolysates' fermentation optimization parameters}

\section{Fermentation duration $\mathbf{t}(\mathrm{h})$}

Table 2 presents the average fermentation duration for each type of sample depending on the yeast strain used. Results didn't reveal any significant difference according to whether the musts were filtered or unfiltered before fermentation. The conversion time of the maximum of sugar contained in the extinct musts varied between $72 \mathrm{~h}$ and $12 \mathrm{oh}$. It's noted that the fermentation carried out in the presence of So lasted less than that carried out in the presence of S1 especially at the level of the unfiltered hydrolysates. In Benin, Mossi et al.
(2018) revealed an optimal fermentation time of 48 hours in their investigations on Sorghum saccharatum stems musts.

\section{Limiting attenuation}

The limiting attenuation values obtained are between $45.28 \pm 1.03 \%$ and $67.57 \pm 1.01 \%$ (Table 3 ). These values revealed that the musts fermented with So had the lowest attenuation values with the exception of B1 and B1.5. Also, the sugar consumption depends on the assimilation capacity of each strain. The limiting attenuation values are significantly different. The highest values were recorded in the non-hydrolyzed samples (Ao; Bo) especially in the presence of the strain S1.

Table 2. Hydrolysates fermentation time (in hours).

\begin{tabular}{|c|c|c|c|c|c|c|c|c|}
\hline & \multicolumn{4}{|c|}{ Filtered hydrolysates (A) } & \multicolumn{4}{|c|}{ Unfiltered hydrolysates (B) } \\
\hline & Ao & Ao.5 & A1 & A1.5 & Bo & Bo.5 & B1 & B1.5 \\
\hline So & $48 \pm 1^{c}$ & $96 \pm 2^{a}$ & $96 \pm 2^{\mathrm{a}}$ & $96 \pm 2^{\mathrm{a}}$ & $72 \pm 1^{c}$ & $72 \pm 2^{b}$ & $72 \pm 2^{b}$ & $72 \pm 2^{b}$ \\
\hline S3 & $72 \pm 2^{\mathrm{c}}$ & $120 \pm 3^{\mathrm{a}}$ & $120 \pm 2^{\mathrm{a}}$ & $120 \pm 3^{\mathrm{a}}$ & $96 \pm 2^{b}$ & $96 \pm 2^{\mathrm{b}}$ & $96 \pm 2^{b}$ & $96 \pm 2^{b}$ \\
\hline
\end{tabular}

Table 3. Limit attenuation of the various hydrolysates.

\begin{tabular}{|c|c|c|c|c|c|c|c|c|}
\hline & \multicolumn{4}{|c|}{ Filtered hydrolysates (A) } & \multicolumn{4}{|c|}{ Unfiltered hydrolysates (B) } \\
\hline & Ao & Ao.5 & A1 & A1.5 & Bo & Bo.5 & B1 & B1.5 \\
\hline So & $\begin{array}{l}63.64 \pm \\
1.02^{\mathrm{a}}\end{array}$ & $\begin{array}{l}52.73 \pm \\
1.00^{d}\end{array}$ & $\begin{array}{l}56.06 \pm \\
1.01^{\mathrm{c}}\end{array}$ & $\begin{array}{l}45.28 \pm \\
1.03^{\mathrm{e}}\end{array}$ & $\begin{array}{l}59.02 \pm \\
1.01^{b}\end{array}$ & $\begin{array}{l}50.00 \pm \\
1.02^{\mathrm{d}}\end{array}$ & $\begin{array}{l}62.26 \pm \\
1.02^{\mathrm{a}}\end{array}$ & $\begin{array}{l}57.63 \pm \\
1.01^{\mathrm{b}, \mathrm{c}}\end{array}$ \\
\hline S1 & $\begin{array}{l}67.57 \pm \\
1.01^{\mathrm{a}}\end{array}$ & $\begin{array}{l}60.00 \pm \\
1.02^{c}\end{array}$ & $\begin{array}{l}56.60 \pm \\
1.03^{\mathrm{d}}\end{array}$ & $\begin{array}{l}52.63 \pm \\
1.00^{f}\end{array}$ & $\begin{array}{l}63.64 \pm \\
1.02^{b}\end{array}$ & $\begin{array}{l}53.06 \pm \\
1.02^{\mathrm{e}, \mathrm{f}}\end{array}$ & $\begin{array}{l}53.33 \pm \\
1.00^{\mathrm{e}, \mathrm{f}}\end{array}$ & $\begin{array}{l}55 \cdot 5^{6 \pm} \\
1.02^{\mathrm{d}, \mathrm{e}}\end{array}$ \\
\hline
\end{tabular}

In the same line, the values sharing no letters are significantly different $(\mathrm{P}<5 \%)$ according to ANOVA and Tukey's multiple comparison tests.

\section{Ethanol's final content (Pexp: g/L)}

Table 4 presents the results obtained from the evaluation of the ethanol final content of the different samples. The ethanol final contents are significantly different and correspond to the alcoholic degrees previously obtained. For the non-hydrolyzed samples, the ethanolic fermentation resulted in final ethanol contents varying between $8.46 \pm 1.02 \mathrm{~g} / \mathrm{L}$ and $100.69 \pm$
$3.01 \mathrm{~g} / \mathrm{L}$. For the hydrolysates, ethanolic fermentation led to final contents of ethanol varying between $99.98 \pm 3.01 \mathrm{~g} / \mathrm{L}$ and $223.69 \pm$ $1.02 \mathrm{~g} / \mathrm{L}$. The best final title $(223.69 \pm 1.02) \mathrm{g} / \mathrm{L}$ is obtained during the fermentation of the substrate having received $1 \mathrm{~g}$ of cellulase and filtered before the fermentation phase (A1) in the presence of Saccharomyces carlsbergensis (So). These results are similar to the values (19.82 to $37.83 \mathrm{~g} / \mathrm{L}$ ) obtained in Brazil by Pacheco et al. 
(2010) on the same raw material treated with hydrochloric acid (3\%) with delignification with $\mathrm{NaOH}(2 \%)$.

\section{Ethanol productivity (Qp: g/L/h)}

Table 5 presents the results of ethanol productivity by the yeast strains used. The productivities recorded for the different samples were significantly different $(\mathrm{P}=0.000)$ whatever strain considered. Results show that the productivity of alcohol depends both on the type of microorganisms and the fermented substrate. The lowest ethanol productivity $(0.12 \pm 0.02$ $\mathrm{g} / \mathrm{L} / \mathrm{h}$ ) is obtained during the fermentation of the sample which has not received an enzyme and is fermented with the strain S1. However, it's markedly high in terms of hydrolysates especially in the presence of So. The highest productivity $(2.33 \pm 0.02 \mathrm{~g} / \mathrm{L} / \mathrm{h})$ was recorded for sample A1 followed by $1.96 \pm 0.03 \mathrm{~g} / \mathrm{L} / \mathrm{h}$ and $1.89 \pm 0.02$ $\mathrm{g} / \mathrm{L} / \mathrm{h}$ obtained respectively in samples B1.5 and Bo.5 in the presence of So. This result is similar to the value $(2.7 \mathrm{~g} / \mathrm{L} / \mathrm{h})$ obtained in Brazil by Rocha et al. (2009) on the same raw material pretreated with dilute sulfuric acid. The results of these authors confirm the productivities obtained in lignocellulosic residues in the present work.

Table 4. Ethanol final content in various hydrolysates (g/L).

\begin{tabular}{|c|c|c|c|c|c|c|c|c|}
\hline & \multicolumn{4}{|c|}{ Filtered hydrolysates (A) } & \multicolumn{4}{|c|}{ Unfiltered hydrolysates (B) } \\
\hline So & $\begin{array}{l}21.91 \pm \\
1.05^{\mathrm{g}}\end{array}$ & $\begin{array}{l}156.86 \pm \\
2.01^{b}\end{array}$ & $\begin{array}{l}223.69 \pm \\
1.02^{\mathrm{a}}\end{array}$ & $\begin{array}{l}147.05 \pm \\
2.03^{c}\end{array}$ & $\begin{array}{l}100.69 \pm \\
3.01^{f}\end{array}$ & $\begin{array}{l}136.05 \pm \\
2.08^{d}\end{array}$ & $\begin{array}{l}123.00 \pm \\
2.03^{\mathrm{e}}\end{array}$ & $\begin{array}{l}141.11 \pm \\
2.00^{d}\end{array}$ \\
\hline $\mathrm{S} 1$ & $\begin{array}{l}8.46 \pm \\
1.02^{g}\end{array}$ & $\begin{array}{l}150.05 \pm \\
1.03^{\mathrm{b}}\end{array}$ & $\begin{array}{l}99.98 \pm \\
3.01^{\mathrm{e}}\end{array}$ & $\begin{array}{l}180.90 \pm \\
1.06^{\mathrm{a}}\end{array}$ & $\begin{array}{l}14.87 \pm \\
1.02^{\mathrm{f}}\end{array}$ & $\begin{array}{l}178.05 \pm \\
1.02^{\mathrm{a}}\end{array}$ & $\begin{array}{l}136.76 \pm \\
1.02^{c}\end{array}$ & $\begin{array}{l}130.20 \pm \\
1.01^{\mathrm{d}}\end{array}$ \\
\hline
\end{tabular}

In the same line, the values sharing no letters are significantly different $(\mathrm{P}<5 \%)$ according to ANOVA and Tukey's multiple comparison tests.

Table 5. Ethanol productivity of various hydrolysates $(\mathrm{g} / \mathrm{L} / \mathrm{h})$.

\begin{tabular}{|c|c|c|c|c|c|c|c|c|}
\hline & \multicolumn{4}{|c|}{ Filtered hydrolysates (A) } & \multicolumn{4}{|c|}{ Unfiltered hydrolysates (B) } \\
\hline So & $\begin{array}{l}0.46 \pm \\
0.02^{h}\end{array}$ & $\begin{array}{l}1.63 \pm \\
0.03^{\mathrm{e}}\end{array}$ & $\begin{array}{l}2.33^{ \pm} \\
0.02^{\mathrm{a}}\end{array}$ & $\begin{array}{l}1.53 \pm \\
0.02^{f}\end{array}$ & $\begin{array}{l}1.40 \pm \\
0.01^{\mathrm{g}}\end{array}$ & $\begin{array}{l}1.89 \pm \\
0.02^{c}\end{array}$ & $\begin{array}{l}1.71 \pm \\
0.03^{d}\end{array}$ & $\begin{array}{l}1.96 \pm \\
0.01^{b}\end{array}$ \\
\hline $\mathrm{S} 1$ & $0.12 \pm 0.02^{h}$ & $\begin{array}{l}1.25 \pm \\
0.01^{\mathrm{e}}\end{array}$ & $\begin{array}{l}0.83^{ \pm} \\
0.02^{f}\end{array}$ & $\begin{array}{l}1.51 \pm \\
0.01\end{array}$ & $\begin{array}{l}0.15 \pm \\
0.03^{\mathrm{g}}\end{array}$ & $\begin{array}{l}1.85 \pm \\
0.03^{a}\end{array}$ & $\begin{array}{l}1.42 \pm \\
0.01^{\mathrm{d}}\end{array}$ & $\begin{array}{l}1.36 \pm \\
0.02^{c}\end{array}$ \\
\hline
\end{tabular}

In the same line, the values sharing no letters are significantly different $(\mathrm{P}<5 \%)$ according to ANOVA and Tukey's multiple comparison tests.

\section{Ethanol production yield (Yp/s: g/kg)}

Significantly difference between ethanol production yields was observed, with high value $(101.77 \pm 2.01 \mathrm{~g} / \mathrm{kg}$ to $231.88 \pm 1.06 \mathrm{~g} / \mathrm{kg})$ for samples which have been previously hydrolyzed (Table 6). The hydrolyzate filtered before fermentation (A1) and fermented with So presented the best yield in ethanol production $(231.88 \pm 1.06) \mathrm{g} / \mathrm{kg}$ followed by $(187.97 \pm 1.03)$ $\mathrm{g} / \mathrm{kg}$ obtained with A1.5 and $(184.93 \pm 1.05) \mathrm{g} / \mathrm{kg}$ obtained with Bo.5 sample in the presence of S1.
These values are below the values $0.38 \mathrm{~g} / \mathrm{g}$ and $0.47 \mathrm{~g} / \mathrm{g}$ obtained in Brazil by Rocha et al. (2009) by performing basic pretreatment and diluted acid, respectively. The difference observed could be attributed to the nature and agro-ecological conditions of the raw material and the pretreatment process used.

\section{Production efficiency (Ey: \%)}

The efficiency of the ethanolic production yield evaluated made it possible to have the results of 
Table 7. The analysis of results revealed that the efficiency rates obtained are significantly different except that in the presence of S1, the samples A1.5 and Bo.5 ( $\mathrm{P}>0.05)$. The strain So was more effective especially on the sample A1 with (42.94 \pm
2.04\%) followed by the strain $\mathrm{S} 1$ on samples A1.5 and Bo.5 with respectively $(34.81 \pm 1.04 \%)$ and $(34.25 \pm 1.05 \%)$. The hydrolyzate A1 remains the most suitable for good alcoholic fermentation for intensive production of bioethanol.

Table 6. Ethanol production yield of the various hydrolysates $(\mathrm{g} / \mathrm{kg})$.

\begin{tabular}{lllllllll}
\hline \multicolumn{3}{c}{ Filtered hydrolysates (A) } & \multicolumn{5}{c}{ Unfiltered hydrolysates (B) } \\
\multicolumn{1}{c}{ Ao } & Ao.5 & A1 & A1.5 & Bo & Bo.5 & B1 & B1.5 \\
\hline So & $22.42 \pm$ & $161.01 \pm$ & $231.88 \pm$ & $153.43 \pm$ & $104.37 \pm$ & $139.25 \pm$ & $127.91 \pm$ & $147.12 \pm$ \\
& $2.00^{\mathrm{h}}$ & $1.03^{\mathrm{b}}$ & $1.06^{\mathrm{a}}$ & $1.04^{\mathrm{c}}$ & $2.02^{\mathrm{g}}$ & $2.03^{\mathrm{e}}$ & $1.08^{\mathrm{f}}$ & $1.03^{\mathrm{d}}$ \\
& & & & & & \\
S1 & $8.56 \pm$ & $153.84 \pm$ & $101.77 \pm$ & $187.97 \pm$ & $15.06 \pm$ & $184.93 \pm$ & $139.95 \pm$ & $133.11 \pm$ \\
& $0.03^{\mathrm{g}}$ & $3.02^{\mathrm{b}}$ & $2.01^{\mathrm{e}}$ & $1.03^{\mathrm{a}}$ & $1.01^{\mathrm{f}}$ & $1.05^{\mathrm{a}}$ & $1.03^{\mathrm{c}}$ & $1.02^{\mathrm{d}}$ \\
\hline
\end{tabular}

In the same line, the values sharing no letters are significantly different $(\mathrm{P}<5 \%)$ according to ANOVA and Tukey's multiple comparison tests.

Table 7. Efficiency of production yield of the various hydrolysates (\%).

\begin{tabular}{|c|c|c|c|c|c|c|c|c|}
\hline & \multicolumn{3}{|c|}{ Filtered hydrolysates (A) } & \multicolumn{5}{|c|}{ Unfiltered hydrolysates (B) } \\
\hline & Ao & Ao.5 & A1 & A1.5 & Bo & Bo.5 & B1 & B1.5 \\
\hline So & $\begin{array}{l}4.15 \pm \\
0.21^{f}\end{array}$ & $\begin{array}{l}29.82 \pm \\
1.03^{b}\end{array}$ & $\begin{array}{l}42.94 \pm \\
2.04^{\mathrm{a}}\end{array}$ & $\begin{array}{l}28.41 \pm \\
1.03^{b, c}\end{array}$ & $\begin{array}{l}19.33 \pm \\
0.11^{\mathrm{e}}\end{array}$ & $\begin{array}{l}25 \cdot 79 \pm \\
0.22^{\mathrm{c}, \mathrm{d}}\end{array}$ & $\begin{array}{l}23.69 \pm \\
1.02^{d}\end{array}$ & $\begin{array}{l}27.24 \pm \\
1.03^{\mathrm{b}, \mathrm{c}}\end{array}$ \\
\hline S1 & $\begin{array}{l}1.59 \pm \\
0.01^{\mathrm{e}}\end{array}$ & $\begin{array}{l}28.49 \pm \\
1.03^{b}\end{array}$ & $\begin{array}{l}1.85 \pm \\
1.02^{\mathrm{d}}\end{array}$ & $\begin{array}{l}34.81 \pm \\
1.04^{\mathrm{a}}\end{array}$ & $\begin{array}{l}2.79 \pm \\
0.02^{\mathrm{e}}\end{array}$ & $\begin{array}{l}34.25 \pm \\
1.05^{\mathrm{a}}\end{array}$ & $\begin{array}{l}25.92 \pm \\
1.02^{\mathrm{c}}\end{array}$ & $\begin{array}{l}24.65 \pm \\
1.02^{\mathrm{c}}\end{array}$ \\
\hline
\end{tabular}

\section{Conclusion}

The present study has allowed us to assess cashew apple residues biofuel potential by fermentation in the presence of the yeasts Saccharomyces carlsbergensis and Saccharomyces cerevisiae for the production of second generation bioethanol. The study of enzymatic hydrolysis kinetics showed the release of fermentable sugars and few phenolic compounds during the process. The musts obtained from the hydrolysates of pretreated cashew apple residues revealed very good performance of the yeasts after fermentation and distillation.

\section{Conflict of interest statement}

Authors declare that they have no conflict of interest.

\section{References}

Aboh, A. B., Dougnon, J. T., Atchade, G. S. T., Tandjiekpon, A. M., 2011. Effet d'aliments à base de pomme cajou sur les performances pondérale et la carcasse des canetons en croissance au Bénin. Int. J. Biol. Chem. Sci. 5 (6), 2407-2414.

Adjou, E. S., Gbaguidi, B. A., Dègnon, R. G., Dahouenon-Ahoussi, E., Soumanou, M. M., Sohounhloue, D. C.K., 2017. Potential of cashew apples as valuable raw materials in food industry and biotechnology in Africa: A Review. Elixir Biosci. 108, 47644-47647.

Agbangnan, D., C. P., Gbohaïda, V., Bothon, F.T.D., Kanfon, R. E., Avlessi, F., Wotto, D. V., Sohounhloue, K. C. D. 2018a. Nutritional profile and chemical composition of juices of two cashew apple's varieties of Benin. Chem. J. 
4(4), 91-96.

Agbangnan, D. C. P., Gbohaïda, V., Koudoro, Y. A., Kanfon, R. E., Wotto, D. V., Sohounhloue, C. K. D., 2018b. Stability study of polyphenols extracted from the leaf sheath of red sorghum (sorghum caudatum) from benin. Int. J. Adv. Res. 6(10), 588-595.

Belmokhtar, N., 2012. Etude de la saccharification enzymatique du miscanthus par des cocktails cellulolytiques de Trichoderma reesei. Thèse de doctorat, Université de Reims ChampagneArdenne, 196p.

Boussarsar, H., 2008. Application de traitements thermique et enzymatique de solubilisation et saccharification de la fraction hemicellulosique en vue de la valorisation de la bagasse de canne à sucre, Doctorat d'Etat, Université de Reims Champagne-Ardenne.

Chundawat, S.P.S., Beckham, G.T., Himmel, M.E., Dale, B.E., 2011. Deconstruction of lingocellulosic biomass to fuels and chemicals. Ann. Rev. Chem. Biomol. Eng. 2, 121-145.

Didderen, I., Destain, J., Thonart, P., 2010. La Production de Bioéthanol à Partir de la Biomasse Lignocellulosique. Forêt Wallonnen. 104, 39-45.

Dubois, M., Gilles, K. A., Hamilton, J. K., Pebers, P. A., Smith, F., 1956. Colorimetric method for determination of sugars and related substances. Anal. Chem. 28(3), 350-356.

Eloutassi, N., Louaste, B., Boudine, L., Remmal, A., 2014. Valorisation de la biomasse lignocellulosique pour la production de bioéthanol de deuxième génération. Rev. Ener. Renouvel. 17(4), 600-609.

Gbohaïda, V., Kouwanou, C. S., Agbangnan, D. P. C., Adjou, S. E., Avlessi, F., Sohounhloué, K. C. D., 2018b. Biofuel power of bioethanol obtained by enzymatic biocatalysis from cashew apple bagasse with Saccharomyces carlsbergensis and Saccharomyces cerevisiae. Int. J. Green Herbal Chem. Sec. A. 7(3), 541550.

Gbohaïda, V., Agbangnan, D. C. P., Bothon, E. T. D., Avlessi, F., Wotto, V., Sohounhloue, K. C. D., 2018a. Alternatives for valorization of agricultural resources of low commercial value in Benin: Production of first generation's bioethanol: A review. Chem. Res. J. 3(4), 9-16.

Gbohaïda, V., Mèdoatinsa, S. E., Nonviho, G., Bogninou-Agbidinoukoun, G. S. R., Agbangnan, D. C. P., Sohounhloué, C. K. D.,
2015. Etude chimique et évaluation de l'Influence de la granulométrie sur la cinétique d'extraction des polyphénols naturels de Pterocarpus erinaceus acclimaté au Bénin. Int. J. Innov. Appl. Stud. 12(2), 325-333.

Gbohaïda, V., Mossi, I., Adjou, E.S., Agbangnan Dossa, C.P., Wotto, D.V., Avlessi, F., Sohounhloue, D. C. K., 2016. Evaluation du pouvoir fermentaire de Saccharomyces cerevisiae et de $S$. carlsbergensis dans la production de bioéthanol à partir du jus de la pomme cajou. J. Appl. Biosci. 101, 9643-9652.

Ghysel, F., Godin, B., Flamin, C., Delfosse, P., Delcarte, J., Stilmant, D., 2010. Valorisation énergétique des fourrages: Comparaison de trois filières, enjeux et opportunités. Journées AFPF - Les usages émergents des prairies et des fourrages, pp.1-15.

Jacquet, N., Vanderghem, C., Blecker, C., Paquot, M. 2010. La steam explosion: Application en tant que prétraitement de la matière lignocellulosique. Biotechnol. Agron. Soc. Environ. 14(2), 561-566.

Kouwanou, C. S., Agbangnan, D., C. P., Adjou, E. S., Tchobo, F. P., Bonou, C., Soumanou, M. M., Sohounhloué, K. C. D., 2018. Physicochemical and enzymatic hydrolysis of Eichhornia crassipes for the production of secondgeneration bioethanol. Amer. J. Chem. 8(2), 41-44.

Mossi, I., Kouwanou, C. S., Agbangnan, C. P. D., Adjou, E. S., Gbohaïda, V., Sohounhloue, D. C. K., 2018. Production du bioéthanol par fermentation du moût de tiges de Sorghum saccharatum (L.) du Bénin. Rev. Int. Sci. Appl. 1(4), 29-35.

Novidzro, K. M., Agbodan, K. A., Koumaglo, K. H., 2013. Etude de la performance de quatre souches de saccharomyces cerevisiae au cours de la production d'éthanol à partir des moûts de sucrose enrichis. J. Soc. Ouest-Afr. Chim. $35,1-7$.

Padonou, S. W., Olou, D., Houssou, P., Karimou, K., Todohoue, M. C., Dossou, J., Mensah, G. A., 2015. Comparaison de quelques techniques d'extraction pour l'amélioration de la production et de la qualité du jus de pommes d'anacarde. J. Appl. Biosci. 96, 9063-9071.

Prommajak, T., Leksawasdi, N., Rattanapanone, N., 2014. Biotechnological valorization of cashew apple: a review. CMU J. Nat. Sci. 13(2), 159-182. 
Rocha, M. V. P., Rodrigues, T. H. S., Macedo, G. R., Gonçalves, L. R. B., 2009. Enzymatic hydrolysis and fermentation of pretreated cashew apple bagasse with alkali and diluted sulfuric acid for bioethanol production. Appl. Biochem. Biotechnol. 155, 407-417.

Sidney, W., 1984. Official Methods of Analysis of the Association of Official Analytical Chemists, Inc. 1111 North Nineteenh, Street Suite 210, Alington, Virginia 22209 USA, Fourteenth Edition.

Soro, D., 2012. Couplage de procédés membranaires pour la clarification et la concentration du jus de pomme de cajou: performances et impacts sur la qualité des produits. Thèse de doctorat, Université de Montpellier, 156p.

Vaitheki, S., Deepa, B., 2016. A comparative study on the production of bioethanol from individual and mixed fruit wastes. Imperial $\mathrm{J}$. Interdiscipl. Res. 2(5), 652-656.

Venkatramana, P., Senthil Murugan, S., Shyama, K., Biju, C., Patki, H. S., Sunanda, C., 2018. Qualitative and quantitative analysis of phytochemicals in cashew apple waste. Indian $\mathrm{J}$. Natural Sci. 8(49), 14459-14462.

Ware, P., Shinde, D. N., Ansari, I., 2019. Extraction and characterization of bioethanol as future fuel. J. Emerg. Technol. Innov. Res. 6(5), 206212.

\section{How to cite this article:}

Gbohaïda, V., Kouwanou, S. C., Bothon, F. T. D., Olayé, T., Agbangnan, D. C. P., Avlessi, F., Sohounhloué, K. C. D., 2020. Performance of Saccharomyces carlsbergensis and Saccharomyces cerevisiae yeasts in the formulation of bioethanol from cashew apple residues. Int. J. Curr. Res. Biosci. Plant Biol. 7(3), 15-25.

doi: https://doi.org/10.20546/ijcrbp.2020.703.002 